\title{
Inhalt
}

\section{H. H. Bielfeld}

Vorwort . . . . . . . . . . . . . . . . III

Inhaltsverzeichnis . . . . . . . . . . . . . . V

Verzeichnis der Konferenzteilnehmer und der Mitarbeiter dieses Sammelbandes . . . VIII

Verzeichnis einiger in deutschen Aufsätzen verwendeter Abkürzungen . . . . . . . XI

W. TASZYCKI

Klasyfikacja słowiańskich nazw miejscowych znaczeniowa a formalna . . . . . . . 1

W. Steinitz

Zu vorrussischen Namen und ihrer Aufnahme und Wiedergabe im Russischen . . . 7

S. HrabeC

Nazwy gruntowe województwa łódzkiego. Podział semantyczny . . . . . . . 15

J. StanisLav

Z toponomastiky Vel'kej Moravy a starého Slovenska . . . . . . . . . . . 21

R. KraJCovié

*Metódy a perspektívy výskumu slovanských služobníckych osadných názvov . . . . 30

I. LUTTERER

Svědectví místních jmen s př́vlastkovým určením o národnostních a hospodářských

poměrech v Čechách . . . . . . . . . . . . 34

*F. ZimmermanN

Die Slawistik in der Namenforschung des burgenländischen Raumes . . . . . . . 39

E. Petrovici-I. PÁtrut

О румынской ономастике славянского происхождения. . . . . . . . . . . . 46

E. ZaImov

Les noms d'habitants dans la toponymie bulgare . . . . . . . . . . . . 52

*W. THORNDAHL

Slawische Ortsnamen in Dänemark . . . . . . . . . . . . . . . 56

R. Frscher

Zu den Anfängen der slawistischen Namenforschung. Die Versuche Rat Grüners auf Anregung Goethes ................ 71

E. SCHWARZ

Deutsche und slawische Orts- und Flußnamen in Nordostbayern (Literaturhinweis) $\quad 80$ 
E. EICHLER

Zur Geographie und Chronologie der slawischen Namen in Nordostbayern . . . . . 81

*H. NaUmanN

Mischnamen in Nordostbayern und angrenzenden Gebieten . . . . . . . . . . . 88

H. WALther

Deutsche und slawische Siedlung im oberen Maingebiet . . . . . . . . . . . 95

E. MüLLER

Reste slawischer Siedlung im Kreis Heiligenstadt . . . . . . . . . . . . . . . . 110

M. BАTHE

Der deutsche Zetazismus im Spiegel slawischer Ortsnamen aus ottonischer Zeit . . . 119

S. WAUER

Zum Problem der polabisch-sorbischen Grenze in den Kreisen Schönebeck und Zerbst 131

*W. WENzEL

Die slawische Besiedlung des Schweinitzer Landes im Lichte der Ortsnamen . . . . 137

F. REDLICH

Doppelnamigkeit in der Niederlausitz . . . . . . . . . . . . . . . . 146

*W. Sperber

Sorbisch-deutsche Übersetzungsentsprechungen bei Flurnamen . . . . . . . 156

*J. BILEK

Pflanzen und Tiere in den slavischen Landschaftsnamen Mecklenburgs . . . . . . 162

*T. WrtkowskI

Zu einigen von Trautmann nicht oder nur unbefriedigend gedeuteten Ortsnamen . . 173

*F. HrNze

Die namenkundlichen Arbeiten von Friedrich Lorentz (1870-1937) . . . . . . . 182

*T. MrLEwSEI

Słowiańskie imiona osobowe z pierwiastkiem werbalnym $\mathrm{w}$ pierwszym czlonie na tle porównawczym . . . . . . . . . . . . . . . . . . . . . . . . . 191

D. Freydank

Ostseeslawische Vollnamen mit hypokoristischer Wurzel im ersten Glied . . . . . . 198

J. OTREBSKI

Namen von zwei Jatwingerstämmen . . . . . . . . . . . . . . . . . . . . 204

*V. Blanár

Využitie jazykových prostriedkov $\mathrm{v}$ rozličných sústavách slovanských osobných

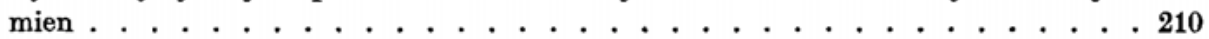

D. Krandžalov

Sur les méthodes de vérification de la nationalité des Valaques-Vlaques dans les

Carpathes et dans les Balkans au Moyen Age à l'aide des noms de personnes . . . . . 216

*A. de Vincenz

Probleme und Grenzen der strukturellen Namenforschung . . . . . . . . . . 223

V. SMILAUER

Cestou k slovanskému atlasu onomastickému . . . . . . . . . . . . . 228 
S. Rospond

Das Problem des toponomastischen Atlasses der Slawen . . . . . . . . . 232

S. UTĚ̌̌ENÝ

O možnostech výzkumu mikrotononymie $\mathrm{v}$ rámci nářečních slovníkových anket -

zvláště v rámci slovanského jazykového atlasu . . . . . . . . . . 235

*H. ScHaLL

Die polabischen Flurnamen um Drefáhl, Kreis Parchim . . . . . . . . 238

W. ZÜHLSDORFF

Südwestmecklenburgischer Flurnamen-Atlas _ . . . . . . . . . 258

J. SvOBODA

K slovanské onomastické terminologii . . . . . . . . . . . . . . 261

M. KARÁs

Uwagi o terminologii onomastycznej. . . . . . . . . . . . . . . . 274

V. SMTLAUER

Ze skušeností z onomastického casopisu a semináře . . . . . . . . . . 283 